\title{
A comment on "Morphologic and genetic characterization of Corsican and Sardinian trout with comments on Salmo taxonomy" by Delling et al. (2020): protected Tyrrhenian trouts must be named
}

\author{
Gaël P.J. Denys ${ }^{1,2, *}$ \\ ${ }^{1}$ Unité Mixte de Service Patrimoine Naturel - Centre d'expertise et de données (UMS 2006 OFB - CNRS - MNHN), Muséum national \\ d'Histoire naturelle, 36 rue Geoffroy-Saint-Hilaire CP 41, Paris 75005, France \\ ${ }^{2}$ Laboratoire de Biologie des organismes et écosystèmes aquatiques (UMR BOREA 8067), MNHN, CNRS, IRD, SU, UCN, UA, 57 rue \\ Cuvier CP26, Paris 75005, France
}

Received: 24 November 2020 / Accepted: 2 February 2021

\begin{abstract}
The introduction of the use of molecular data has caused debates on the taxonomy of Corsican and Sardinian trouts, also referred to as Tyrrhenian trouts (i.e. Salmo trutta, Salmo macrostigma, Salmo cettii). A recent study by Delling et al. (2020) (Morphologic and genetic characterization of Corsican and Sardinian trout with comments on Salmo taxonomy. Knowl Manage Aquat Ecosyst 421: 21) introduces important evidence regarding the taxonomy of these populations. However, their subsequent denomination as Salmo sp., that is, an undefined taxon, could have serious consequences on their future conservation management plans. Considering their threatened status, the Tyrrhenian trouts should be referred to as Salmo trutta until the ongoing taxonomic uncertainty can be unambiguously resolved. These populations must then be treated as an Evolutionary Significant Unit (ESU) or as an Operational Conservation Unit (OCU) for further conservation managements plans, as already done for other Mediterranean trout lineages.
\end{abstract}

Keywords: Salmo trutta / Corsica / Sardinia / conservation / taxonomy

\begin{abstract}
Résumé - Un commentaire sur "Morphologic and genetic characterization of Corsican and Sardinian trout with comments on Salmo taxonomy" par Delling et al. (2020). La taxonomie des truites corses et sardes, également appelées truites tyrrhéniennes (i.e. Salmo trutta, Salmo macrostigma, Salmo cettii) a fait l'objet de débats depuis l'utilisation des premières données moléculaires. Une étude récente de Delling et al. (2020) (Morphologic and genetic characterization of Corsican and Sardinian trout with comments on Salmo taxonomy. Knowl Manage Aquat Ecosyst 421: 21) a présenté des éléments importants sur la taxonomie de ces populations. Cependant, leur dénomination comme Salmo sp. - i.e. espèce non déterminée - qui s'ensuivit, pourrait avoir de graves conséquences en terme de gestion future de la conservation de ces populations. Compte tenu de leur statut menacé, les truites tyrrhéniennes devraient être appelées Salmo trutta jusqu'à ce que l'incertitude taxonomique actuelle puisse être résolue sans ambiguïté. Ces populations doivent ensuite être traitées comme une Unité Évolutive Importante (ESU) ou comme une Unité Opérationnelle de Conservation (OCU) pour les futures gestions de conservation, comme c'est déjà le cas pour d'autres lignées de truites méditerranéennes.
\end{abstract}

Mots clés : Salmo trutta / Corse / Sardaigne / conservation / taxonomie

Tyrrhenian trouts are native of Corsica and Sardinia and belong to the Salmo trutta Linnaeus, 1758 species complex (Berrebi et al., 2019; Delling et al., 2020). Their taxonomy has been extensively debated: alongside a number of other Mediterranean populations, they were first assigned the name

\footnotetext{
*Corresponding author: gael. denys@mnhn.fr
}

Salmo macrostigma (Duméril, 1858), a species originally described from Algeria, due to the presence of a diagnostic colour pattern comprising parr mark being retained in adult individuals (e.g., Boulenger, 1901; Roule, 1933). However, the first molecular studies suggested that Tyrrhenian trouts were more closely affiliated to an Adriatic lineage, which is clearly distinct from North African populations (e.g., 
Schöffmann et al., 2007). In the wake of these results, Kottelat and Freyhof (2007) included the Tyrrhenian trouts within Salmo cettii Rafinesque, 1810 (or potentially Salmo ghigii Pomini, 1941, but the latter name was invalidated by Bianco (2014) and is currently a synonym of Salmo farioides Karaman, 1938). Furthermore, mitochondrial data has demonstrated that $S$. macrostigma is invalid (Tougard et al., 2018), and it is currently considered a junior synonym of S. cettii (Splendiani et al., 2019). Berrebi et al. (2019) conducted molecular investigations, focussed on the Adriatic lineage, and highlighted that eight Corsican populations (U Furcone, A Tassineta, Aqua d'Acelli, E Maghjine, Speloncellu, Pozzi, Val d'Ese, and Lataga Rivers) and three Sardinian populations of the Cixerri basin were genetically-separated from the cluster corresponding to $S$. cettii. Most recently, Delling et al. (2020) analysed both morphological and molecular data and concluded that Tyrrhenian trouts are morphologically distinct from both Atlantic and North African trouts, but that the morphological data are incongruent with mitochondrial lineages. The authors further suggested that their results leave Tyrrhenian trouts without a taxonomic identity and that they should be referred to as Salmo sp. until this issue is resolved.

However, the unique native populations in Corsica and Sardinia are threatened by restocking operations leading to introgression with non-native Atlantic and Mediterranean trout lineages, habitat fragmentation by hydroelectric dams, poaching and competition with non-native rainbow trout Oncorhynchus mykiss (Walbaum, 1792) and brook trout Salvelinus fontinalis (Mitchill, 1814) (e.g., Massidda, 1995; Berrebi, 2015; Lobón-Cerviá et al., 2019). Ancestral (or native) Corsican populations are currently the most conserved and exhibit low intra-population genetic diversity as well as a high level of inter-population differentiation. Sardinian trout populations are more degraded by introgression with domesticated Atlantic trouts (Berrebi et al., 2019).

In France, all brown trout lineages and phenotypes (denominated Salmo trutta ssp.) are protected within the framework of a ministerial order 8/12/1988. The Corsican lineage is also included in Annex II of the European Habitats Directive with the denomination " $S$. trutta macrostigma". Keith and Marion (2002) evaluated the status of the ancestral Corsican trouts "S. trutta macrostigma" as "Critically Endangered". Some important conservation measures were then undertaken to protect the native populations in Corsica, such as the Life program "conservation de la truite macrostigma en Corse" 2003-2009 (see https://truitecorse.org/\#). In Sardinia, some restocking programs focussed on native populations have resulted in the eradication of introgressed trouts (Sabatini et al., 2011, 2018).

Taxonomic changes may exert negative impacts on conservation and management of threatened species (Isaac et al., 2004). In the most recent French national IUCN Red Lists for freshwater fish species, Tyrrhenian trout populations have either been included within $S$. cettii and assessed as Endangered (UICN France et al., 2010), or within S. trutta as Near Threatened (UICN comité français et al., 2019). They have not been considered as a distinct taxonomic unit, and this could negatively impact their conservation in case of a legislative revision. Moreover, IUCN Red List assessments have a great influence on fund allocation for species conservation efforts as well as when changes to legislation and policy are considered. Trouts are among the most prominent freshwater fish species in French conservation and management policies (Bouleau, 2019; Betts et al., 2020). In particular, the ancestral Corsican trout lineage has an important patrimonial value on the island and a change in taxonomic status may be detrimental to its long-term preservation (Keith et al., 2020).

Delling et al. (2020) refers to the Tyrrhenian trout populations as "Salmo sp.". This is detrimental to the conservation measures in favour of these populations, as a species needs to be named, formally identified and recorded in the legislation in order to benefit from conservation measures (Mace, 2004). An undefined species cannot be recorded in any legislative text and can not receive the benefits associated with specific conservation management. Renaming these threatened populations Salmo sp. may therefore adversely affect current and future conservation efforts. It can be argued that it might be better to give a broad name and then characterize lineages using concepts like Evolutionary Significant Units (ESU; see Mayden and Wood, 1995 when considering the spatial distribution of genetic diversity), or Operational Conservation Units (OCU; Dodson et al., 1998, to reflect ESUs and their interaction with socio-economic issues). Such an approach conveys the intrinsic ecological and genetic properties of these populations, and conservation management actions can be undertaken independently of the taxonomical discordance within the Salmo trutta complex (e.g., Tougard et al., 2018; Splendiani et al., 2019). These concepts are already applied to some Mediterranean trout lineages (e.g., Machordom et al., 2000; Almodóvar et al., 2006). Therefore morphological data do not corroborate with molecular data in Delling et al. (2020), this lineage cannot be then considered as a distinct species according to integrative taxonomy (e.g., Padial et al., 2010). In order to safeguard their long-term survival, and based on the available evidence (e.g., Tougard et al., 2018; Delling et al., 2020), Tyrrhenian trout populations should thus be considered as belonging to Salmo trutta pending further studies and a decisive taxonomic resolution, with an additional recognition as an ESU or OCU.

Acknowledgements. I warmly thank M. Hautecœur and A. Dettai for checking the English as well as the anonymous referees who improved the text.

\section{References}

Almodóvar A, Nicola GG, Elvira B, García-Marín JL. 2006. Introgression variability among Iberian brown trout evolutionary significant units: the influence of local management and environmental features. Freshw Biol 51: 1175-1187.

Berrebi P. 2015. Three brown trout Salmo trutta lineages in Corsica described through allozyme variation. J Fish Biol 86: 60-73.

Berrebi P, Caputo Barucchi V, Splendiani A, Muracciole S, Sabatini A, Palmas F, Tougard C, Arculeo M, Marić S. 2019. Brown trout (Salmo trutta L.) high genetic diversity around the Tyrrhenian Sea as revealed by nuclear and mitochondrial markers. Hydrobiologia 826: 209-231.

Betts J, Young RP, Hilton-Taylor C, Hoffmann M, Rodríguez JP, Stuart SN, Milner-Gulland EJ. 2020. A framework for evaluating the impact of the IUCN Red List of threatened species. Conserv Biol 34: 632-643. 
Bianco PG. 2014. An update on the status of native and exotic freshwater fishes of Italy. J Appl Ichthyol 30: 62-77.

Bouleau G. 2019. Politisation des enjeux écologiques: De la forme au motif environnemental. London: ISTE Editions, $179 \mathrm{p}$.

Boulenger GA. 1901. On the occurrence of Salmo macrostigma in Sardinia. Ann Mag Nat Hist (Ser. 7) 8: 14.

Delling B, Sabatini A, Muracciole S, Tougard C, Berrebi P. 2020. Morphologic and genetic characterization of Corsican and Sardinian trout with comments on Salmo taxonomy. Knowl Manage Aquat Ecosyst 421: 21.

Dodson JJ, Gibson RJ, Cunjak RA, Friedland KD, García de Leániz C, Gross MR, Newvury R, Nielsen JL, Power ME, Roy S. 1998. Elements in the development of conservation plans for Atlantic salmon (Salmo salar). Can J Fish Aquat Sci 55: 312-323.

Isaac NJB, Mallet J, Mace GM. 2004. Taxonomic inflation: its influence on macroecology and conservation. Trends Ecol Evol 19: 464-469.

Keith P, Marion L. 2002. Methodology for drawing up a Red List of threatened freshwater fish in France. Aquatic Conserv Mar Freshw Ecosyst 12: 169-179.

Keith P, Poulet N, Denys G, Changeux T, Feuteun E, Persat H. 2020. Les Poissons d'eau douce de France, collection Inventaires \& biodiversité, second edition. Biotope Editions, Mèze, Publications scientifiques du Muséum, Paris, 704 p.

Kottelat M, Freyhof J. 2007. Handbook of European Freshwater Fishes. Cornol, Switzerland: Publication Kottelat.

Lobón-Cerviá J, Esteve M, Berrebi P, Duchi A, Lorenzoni M, Young KA. 2019. Trout and char of central and southern Europe and northern Africa. In Kershner J, Williams J, Lobón-Cerviá J, Gresswell B, eds. Trout and Char of the World. Bethesda: American Fisheries Society, pp. 379-410.

Mace GM. 2004. The role of taxonomy in species conservation. Phil Trans $R$ Soc Lond B 359: 711-719.

Machordom A, Suárez J, Almodóvar A, Bautista JM. 2000. Mitochondrial haplotype variation and phylogeography of Iberian brown trout populations. Mol Ecol 9: 1325-1338.
Massidda P. 1995. Salmo (Trutta) macrostigma in Sardegna. Biol Ambient 5: 40-43.

Mayden RL, Wood RM. 1995. Systematics, species concepts, and the evolutionary significant unit in biodiversity and conservation biology. Am Fish Soc Symp 17: 58-113.

Padial JM, Miralles A, De la Riva I, Vences M. 2010. The integrative future of taxonomy. Front Zool 7: 16.

Roule L. 1933. Le peuplement des cours d'eau de la Corse en poissons. Bull Fr Pêche Piscic 63: 61-62.

Sabatini A, Podda C, Frau G, Cani MV, Musu A, Serra M, Palmas F. 2011. Genetic characterization and artificial reproduction attempt of endemic Sardinian trout Salmo trutta L., 1758 (Osteichthyes, Salmonidae): experiences in captivity. Ital J Zool 78: 20-26.

Sabatini A, Cannas R, Follesa MC, Palmas F, Manunza A, Matta G, Pendugiu AA, Serra P, Cau A. 2018. Restoration of native Mediterranean trout Salmo cettii Rafinesque, 1810 (Actinopterygii, Salmonidae) populations using an electric barrier as mitigation tool. Europ Zool J 85: 137-149.

Schöffmann J, Sušnik S, Snoj A. 2007. Phylogenetic origin of Salmo trutta L. 1758 from Sicily, based on mitochondrial and nuclear DNA analyses. Hydrobiologia 575: 51-55.

Splendiani A, Palmas F, Sabatini A, Caputo Barucchi V. 2019. The name of the trout: considerations on the taxonomic status of the Salmo trutta L., 1758 complex (Osteichthyes: Salmonidae) in Italy. Eur Zool J 86: 432-442.

Tougard C, Justy F, Guinand B, Douzery EJP, Berrebi P. 2018. Salmo macrostigma (Teleostei, Salmonidae): nothing more than a brown trout (S. trutta) lineage? J Fish Biol 93: 302-310.

UICN France, MNHN, SFI, ONEMA, 2010. La liste rouge des espèces menacées en France, Chapitre Poissons d'eau douce de France métropolitaine, Paris, $12 \mathrm{p}$.

UICN comité français, MNHN, SFI, AFB, 2019. La Liste rouge des espèces menacées en France, Chapitre Poissons d'eau douce de France métropolitaine, Paris, $16 \mathrm{p}$.

Cite this article as: Denys GPJ. 2021. A comment on "Morphologic and genetic characterization of Corsican and Sardinian trout with comments on Salmo taxonomy" by Delling et al. (2020): protected Tyrrhenian trouts must be named. Knowl. Manag. Aquat. Ecosyst., $422,6$. 